\title{
REQUEST FOR PROPOSALS
}

The Rule of Law Consortium (ARD/Checchi Joint Venture), under the auspices of the U.S. Agency for International Development, announces the Russia ROL Grants Program under the Russia Contract (CCN\#-0007-C-00-3166-00), and the Ukraine ROL Grants Program under the Slavic Contract (Ukraine, Moldova, Belarus) (CCN\#-0007-C-00-3169-00) for the purpose of creating a stable legal and political environment for developing and strengthening the Rule of Law (ROL) in the transition to democratic, market-based societies in Russia and Ukraine.

Grants will be made to U.S., Russian, and Ukrainian organizations that propose action-oriented programs designed to have a direct impact on change through the Rule of Law. Programs should be designed to strengthen core legal institutions and processes (as well as civil society as it relates to legal development) in order to support general legal reform, encourage an orderly transition to a market economy, protect human rights, and limit the potential for arbitrary exercise of governmental power. All proposals must demonstrate how they will contribute to the sustainability of Rule of Law.

Although support is not limited to any predetermined list of activities, the following are illustrative: increasing public awareness and knowledge of laws and legal procedures; helping citizens organize to advocate changes in the legal system; helping citizens protect their individual and property rights; helping citizens utilize the legal system for the adjudication of conflict; developing systems of private and quasi-public altemative dispute resolution; helping the public remove legal and regulatory constraints on private sector commercial activities; helping the public establish constitutional guarantees of private ownership, commercial activity and public accountability; developing a system of administrative law, public defenders' offices, and other oversight organizations; etc.

Proposals are requested from U.S. not-for-profit (501 C 3), non-govemmental and private voluntary organizations in co-partnership with corresponding entities in Russia or Ukraine. Proposals may originate with the Russian or Ukrainian partner but must be administered via the American partner. In some cases, official public institutions may also be eligible for funding (please refer to guidelines enclosed in the application packet for complete eligibility requirements).

Approximately two million dollars is available under the Russian Program over the course of the Contract period, and one and one-half million dollars is available under the Ukrainian Program over the same period. Most awards will range between \$5,000 and $\$ 100,000$. All proposals require a minimum $25 \%$ match from non-federal sources. The application deadline for the Russian Grants Program is December 2, 1994 and awards will be announced in February 1995. The application deadline for the Ukrainian Grants Program is November 25, 1994 and awards will be announced in January 1995.

For more information about requirements and an official application package, write, fax, call or E-mail:

In Russia: Rule of Law Consortium (ARD/Checchi Joint Venture), Russian Grants Program, ul. Nezhdanovoi d. 6, kv. 24, 103009 Moscow, R., 7-095-229-8219 (fax), 7-095229-8623, e-mail:ard@ard1.law.msk.su

In Ukraine: Rule of Law Consortium (ARD/Checchi Joint Venture), Ukraine Grants Program, 6 Saksaganska St, Kiev, Ukraine 252004, 7-044-220-8505 (fax), 7-044227-5029, e-mail:mg@ruleoflaw.kiev.ua

In the U.S.: Rule of Law Consortium (ARD/Checchi Joint Venture), c/o NIS Regional Grants Program, 1819 L St., NW, Suite 500, Washington, D.C., 20036, 202-8610934 (fax)/0513 (message), o-mail: 74763.1652@CompuServe.com 
ADVERTSEMENT -

REANTS RUSSIAN EXPERIENCE INC.'S

\section{GRE CELEBRATES ITS SUCCESSFUL FIRST SUMMER PROGRAM IN RUSSIA}

Grant's Russian Experience successfully completed its first summer program in Russia with 30 American and Russian students. The American students came from all over the United States and the Russians from all over Russia including places like Kamchatka, Lake Baykal, Novosibirsk, the Caucuses, Moscow and St. Petersburg.

The 8 week program was held in a pansionat (resort hotel) in Zvenig. orod, a favorite vacation spot for elite Moscovites which is located 25 miles outside Moscow. The pansionat has all kinds of sports facilities and sits on the bank of the Moscow River. It is surrounded by pristine fields and forests making it ideal for swimming and outdoor recreation.

Weak days, the American students start each day with four academic hours of intensive Russian language study. During this time, the Russians study political science and economics. The Russians' instructors, brought to Russia by GRE, included a world renowned economist and a Chilean congressman who discussed Chile's transition from Communism.

At least once a week, the students were taken on field trips to such places as Pushkin's apartment and Tolstoy's home in Moscow. These trips were supplemented with organized excursions, usually several a week, to theaters, concerts, night clubs, the circus, etc. In the afternoons, the students participated in organized activities such as playing sports or floating down the river or they headed into Moscow on their own.

The Russian students were nominated by university presidents and members of the Russian partiament. The result was an incredibly talented group of Russian students. These young Russians had an impressive group of parents, amongst them five members of partiament and one of Russia's best known philosophers.

The teachers and staft of GRE are well acquainted with Russian culfure and with many interesting and prestigious Moscovites. Due to these acquaintances, the students in 1994 were afforded very unique interviews and glimpses into Russian lite. They had a private interview with Elena Bonner, widow of Andrei Sakharov and were introduced to Mark Rozovsky, the director of a well known theater, and to Stanislav the closed meeting for Mr. Govoroukhin, a few of the students had the chance to get their pictures taken with Gorbachev.

The students also enjoyed weekly outings at the hotel's Russian banya (bathhouse) and several meals with Russian families in their apartments. The students were invited to the wedding reception of the local leader of the Cossacks, to an ancient ceremony annually held by MGU students at a neighboring summer camp, and to go horseback riding with a local equestrian. Perhaps the fondest memories will be of the many evenings spent singing around a campfire accompanied by one of the several very talented student guitar players. Both the American and Russian students found GRE's program to offer an incredible social and learning experience. The relaxed atmosphere in a resort hotel enabled them to build friendships that witl last a lifetime.

An early sign up is recommended for those interested in being part of the summer of 1995 program because enrollment will again be limited. Prior Russian is not a prerequisite but is recommended.

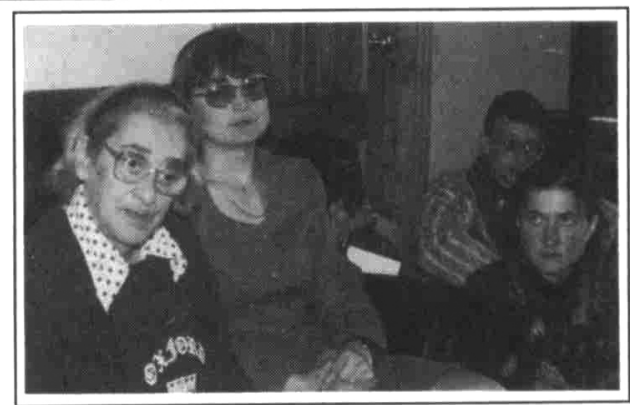

Elena Bonner, widow of Andrei Sakharov, listens to a question during the private interview she gave GRE's students. Beside Mrs. Bonner is GRE's Dean, Dr. Larisa Salamova.

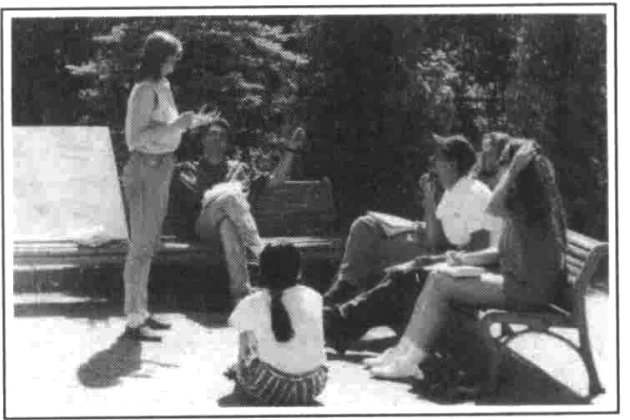

The country setting permitted many of the classes to be held 作 Russian language students.

\section{AMERICAN TEACHERS COMPLEMENTED}

The American students were almost all recommended to GRE's program by their teachers of Russian in America. GRE's Dean, Dr. Larisagram by their teachers of Russian in America. GRE's Dean, Or. Larisastudents and with their preparation.

I have been teaching Russian to foreigners for 10 years," said $\mathrm{Dr}$ Salamova. "Over that period," she said, "I have had the opportunity to assess the intelligence, the intellectual curiosity and the perseverance of literally hundreds of students in the process of learning the Russian language." "Initially," said Dr. Salamova, "I was working with officers from the former Soviet bloc countries and more recently with foreigners from all over the world who have recognized the economic and other opportunities now opening up in Russia Of all those students: caid Pr. "the a gram were as a group certainly amongst the most impressive that (Continued on next page) 


\section{AMERICAN TEACHERS COMPLEMENTED}

\author{
(continued from prior page)
}

According to Dr. Salamova, "They were very intelligent. Those that were not beginning students were well grounded in Russian grammar. They were hard working and they were a genuinely nice group of young people."

"I complement all those teachers of Russian who have had any input in preparing these students," said Dr. Salamova, "and I hope that any of these teachers who are ever in Moscow while our summer program is in session will make the short trip out to beautiful Zvenigorod so that I can complement them personally."

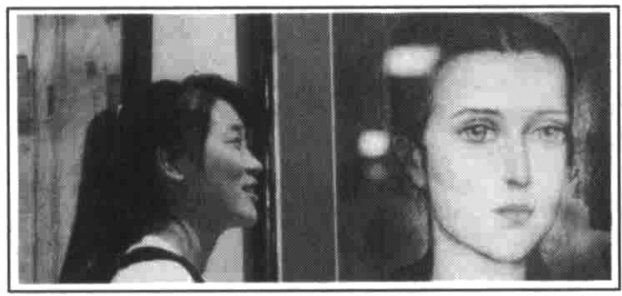

The students attended an exhibition of almost all of Glazunov's paintings. Pictured here with student Kathy Lee is the illustration of Polina that he did for Dostoyevsky's "Player".

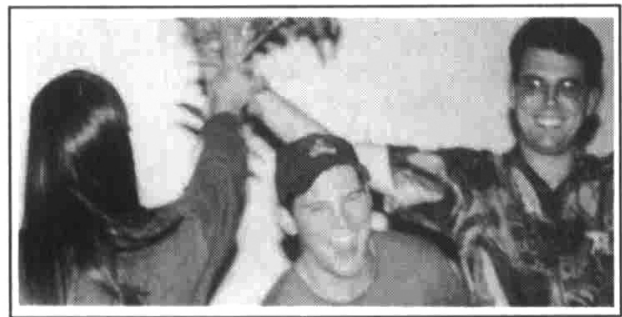

GRE's student body contained many talented musicians permitting a number of musical programs. Mark Caroul put on a recital to which all the guests at the hotel were invited. "This experience and the encouragement received from my fellow students," said Mark, "has made me decide on a career change".



Close by the resort hotel on the Moscow River in which GRE's summer program was held is a Moscow State University summer camp. It is a tradition that in the evening of the longest day of the year, the MGU students at this camp recreate an ancient ceremony. Crowns are woven out of flowers and vines. Songs are sung around a huge bon fire. GRE's students were invited to join in this celebration including the traditional mid night swim in the Moscow river.

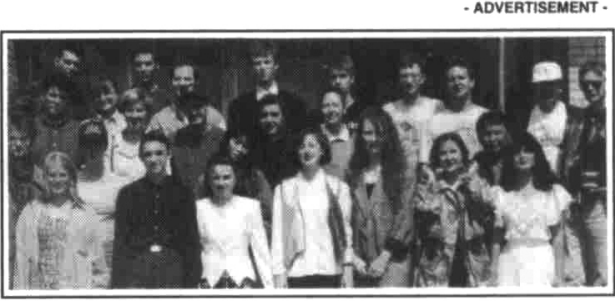

GRE'S first year's students

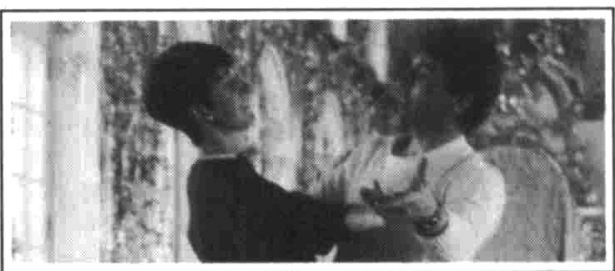

American Nancy Morgan and Russian Vladimir Shimkov in the ball room of the Hermitage.

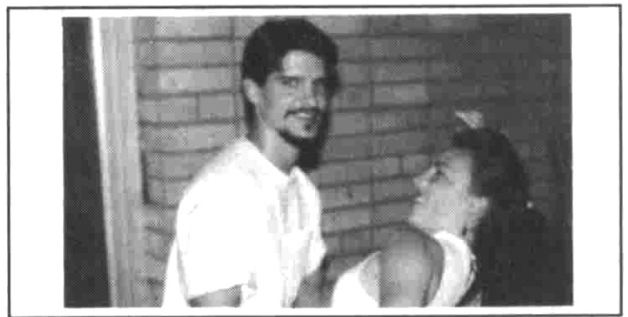

American Bill Converse and Russian Natasha Dounets at the students' Disco.

The fee for the Summer of '95 8 week program is $\$ 3995$ which in cludes airfare from N.Y., room and board, four academic hours of intensive Russian language study each week day, course materials, weekly local tours and a week end in St. Petersburg. Nine credits are usually available through the student's own school for this program or, for an additional fee, through SUNY New Paltz. The airline is FINNAIR.

\section{Grant's Russian Experience Inc.}

7330 Westmoreland Dr. Sarasota, FL 34243

Tel. 1-800-PYCCKOE or 1-813-351-1596; FAX 1-813-351-8440

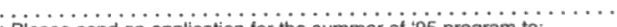
Nam

: Address

: Address

Phone and/or P

Age

School

Years of Russian 


\section{SOVIET POLITICS}

\section{LEADERSHIP STYLE AND SOVIET FOREIGN POLICY}

STALIN,

KHRUSHCHEV,

BREZHNEV

GORBACHEV

James M. Goldgeler

"James Goldgeier offers an imaginative and original argument: leaders bargaining style, developed in domestic politics, affects the way they bargain and manage international crises. This analysis is significantly different from other 'domestic politics' arguments that focus on coalitionbuilding, log-rolling, or cooptation of representatives of powerful domestic groups."-Janice Gross Stein, University of Toronto

Perspectives on Security: Richard Ned Lebow, Series Editor

$\$ 35.00$ hardcover

\section{KHRUSHCHEV'S DOUBLE BIND}

INTERNATIONAL PRESSURES AND DOMESTIC COALITION POLITICS

\section{James G. Richter}

How do world leaders manage the competing priorities of maintaining support at home and credibility in the international arena? James Richter argues that in order to hold power and pursue his political agenda at home, Khrushchev needed to maintain his standing as an effective world leader. His successes - especially in winning concessions from the United Statescontributed to his power base and ability to grant favors and effect change in the Soviet Union.

Perspectives on Security: Richard Ned Lebow, Series Editor

$\$ 45.00$ hardcover

\section{ETHNOPOLITICS AND TRANSITION TO DEMOCRACY}

THE COLLAPSE OF THE USSR AND LATVIA

\section{Rasma Karklins}

The politics of ethnicity is shaping the post-Cold War world. Rasma Karklins argues that ethnicity can be a constructive rather than a destructive force in the transition to democracy. In analyzing the collapse of the Soviet Union and the example of democracy building in Latvia, she demonstrates that applying democratic practices within a multi-ethnic society makes possible the creation of a constructive civic nationalism, respectful of the rights of ethnic groups.

\section{Woodrow Wilson Center} Press

$\$ 17.95$ paperback

\section{THE JOHNS HOPKINS UNIVERSITY PRESS}

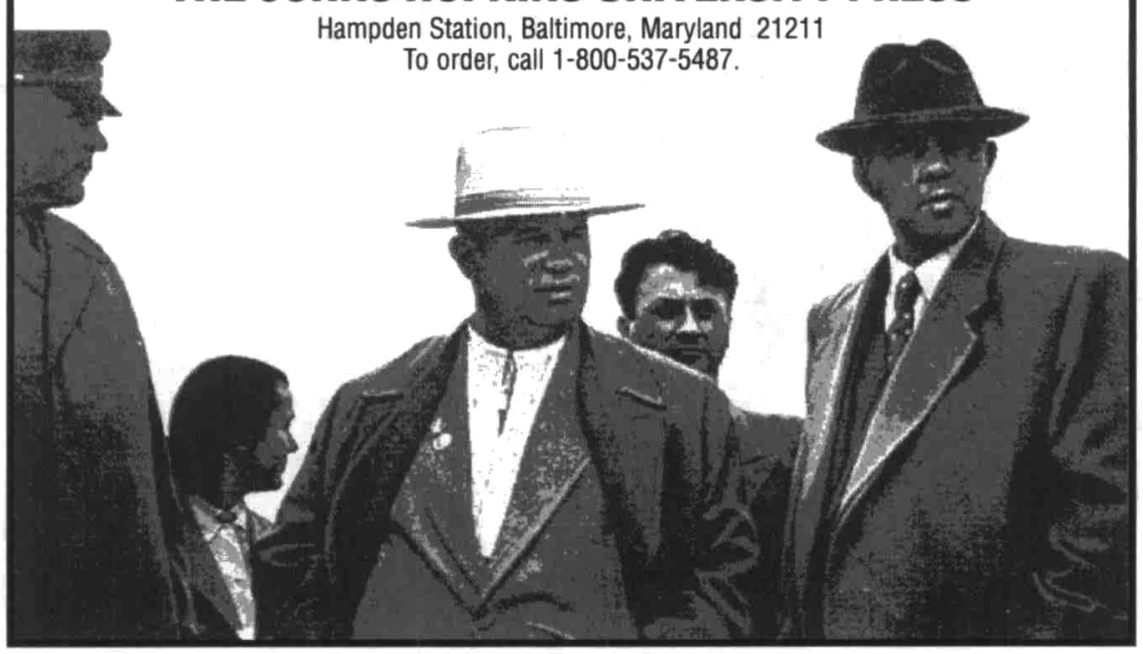




\section{OXFORD UNIVERSITY PRESS}

\section{A History of Russia \\ Fifth Edition \\ NICHOLAS V. RIASANOVSKY \\ University of Califomia, Berkeley \\ "An indispensable textbook. Given its chrono- logical scope, it is remarkably consistent in its quality. The serious scholar can respect its judge- ments and interpretations; the undergraduate can benefit from its organization and clarity of style."-Girish Bhat, State University of New York at Cortland \\ 1993768 pp.; 30 maps, 68 illus. $\$ 38.00$}

\section{Reinterpreting \\ Russian History}

Readings, 860-1860s

Edited by DANIEL H. KAISER, Grinnell

College, and GARY MARKER, State

University of New York at Stony Brook

"The best book of readings ever. This field has been begging for an issue approach reader." -Richard Warner, Mary Washington College 1994464 pp.; 69 illus. and 1 map paper $\$ 17.95$ cloth $\$ 45.00$

\section{Return to Diversity}

\section{A Political History of East Central Europe Since World War II \\ Second Edition}

JOSEPH ROTHSCHILD, Columbia University

"Still the best book available on post-World War

II Eastern Europe. Sophisticated and challengjng, but undergraduates like reading it." - Harriet Freidenreich, Temple University

1993320 pp.; 2 maps

paper $\$ 14.95$ cloth $\$ 39.95$

\section{The Walls Came Tumbling Down}

The Collapse of Communism in

\section{Eastern Europe}

\section{GALE STOKES, Rice University}

"Offers the reader a lucid, elegantly written, and insightful account of the turmoil that accompanied the collapse of communism in Eastern Europe. Eminently suited for college courses in modern Eastern European history."-Gabor Vermes, Rutgers University 1993336 pp. paper $\$ 14.95$ cloth $\$ 25.00$
Aleksandr Nikolaevich Engelgardt's Letters from the Country, 1872-1887

ALEKSANDRNIKOLAEVICH

ENGELGARDT

Translated and Edited by Cathy Frierson, University of New Hampshire

"A very valuable addition to the social history of imperial Russia and the life of the peasants. The book provides a very human picture of country life after the Emancipation of 1861."-Lohr E. Miller, Aubum University at Montgomery 1993304 pp.; 14 illus. paper $\$ 18.95$ cloth $\$ 45.00$

The End of

\section{Communist Power}

Anti-Corruption Campaigns and Legitimation Crisis

LESLIE HOLMES, University of Melbourne

"A most interesting and scholarly analysis of the nature of corruption in communist systems and its direct linkage with the crises of legitimation which have ensued since 1988, and in some cases, continue today."-Anthony R. Brunello, Eckend College

(Europe and the Intemational Order)

1993384 pp.; 2 tables

paper $\$ 16.95$ cloth $\$ 57.00$

\section{Peasant Icons}

Representations of Rural People in Late Nineteenth-Century Russia CATHY A. FRIERSON University of New Hampshire

"Many have touched on this subject, but no one has done it, as a whole, before-so thoroughly, so convincingly, so delightfully, so wonderfully!"-Francis B. Randall, Sarah Lawrence College

1993272 pp.; 16 illus.

paper $\$ 17.95$ cloth $\$ 39.95$

Prices are subject to change. To request an examination copy, write on school letterhead giving full course information, including course name, level, expected enrollment, and your decision deadline, to: Oxford University Press ATTN: College Sales Coordinator

\section{MADISON AYENUE - NEW YORK, NY 10016}




\section{When the Soviet Union Entered World Politics JON JACOBSON}

The dissolution of the Soviet Union has aroused much interest in the USSR's role in world politics during its 74-year history and in how the international relations of the twentieth century were shaped by the Soviet Union. Jacobson examines Soviet foreign relations during the period from the end of the Civil War to the beginning of the first Five-Year Plan, focusing on the problems confronting the Bolsheviks as they sought to promote national security and economic development.

$\$ 40.00$ cloth, $\$ 18.00$ paper

\section{Medieval Russian Culture, Volume II}

\section{Edited by MICHAEL S. FLIER and DANIEL ROWLAND}

These essays challenge received notions about the culture and history of medieval Russia and offer fresh approaches to problems of textual interpretation, the theory of the medieval text, and the analysis of alternative, nonverbal texts. The contributors, international specialists from many disciplines, investigate issues ranging over history, cultural anthropology, art history. and ritual.

California Slavic Studies, 19 $\$ 40.00$ cloth, illustrated

\section{Christianity and the Eastern Slavs}

Volume II: Russian Culture in Modern Times

\section{Edited by ROBERT P. HUGHES and IRINA PAPERNO}

This three-volume collection brings together essays from two international conferences. Volume II explores cultural history from the eighteenth to the twentieth centuries. Volume I examines the history and influences of Christianization from the tenth to the seventeenth century, and Volume III will focus on the literature of the nineteenth and twentieth centuries.

California Slavic Studies, 17 $\$ 55.00$ cloth, illustrated
Also available:

Christianity and the Eastern Slavs Volume I: Slavic Cultures in the Middle Ages Edited by BORIS GASPAROV and OLGA RAEVSKY-HUGHES California Slavic Studies, 16 $\$ 50.00$ cloth

Medieval Russian Culture, Volume I Edited by HENRICK BIRNBAUM and MICHAEL S. FLIER California Slavic Studies, 12 $\$ 50.00$ cloth

\section{At bookstores}

or order toll-free 1-800-822-6657.

\section{University of \\ California Press}

Berkeley Los Angeles New York London 


\section{“Tumarkin has done it again!”*}

*"As in her first inspiring book, Lenin Lives! she arrests the reader with compelling and fascinating detail."

-Richard Stites, Georgetown University

"A most readable as well as instructive book." -Adam Ulam, Harvard University

"Tumarkin has thoroughly researched the development of the cult, and her findings will be valuable to any study of Soviet society." - Michael Kenney, Boston Globe

"A beautiful, moving account."

-Daniel Yergin, Pulitzer Prize-winning author of The Prize

In bookstores now or call toll free 800-331-3761

\section{- BasicBooks}

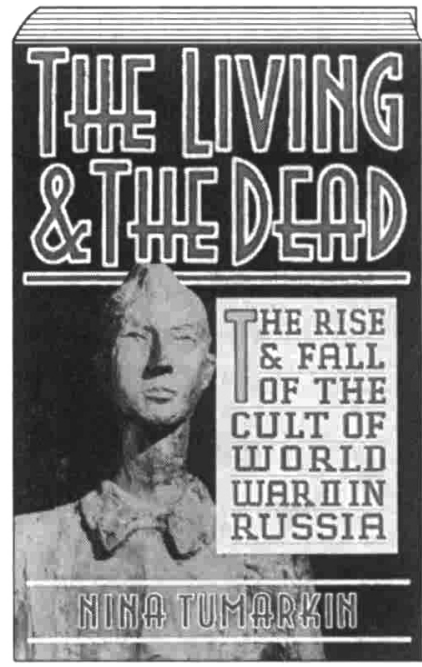

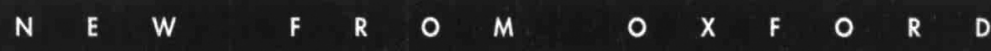

\section{THE POCKET OXFORD RUSSIAN DICTIONARY}

Edited by COLIN HOWLET, NIGEL RANKIN, and DELLA THOMPSON

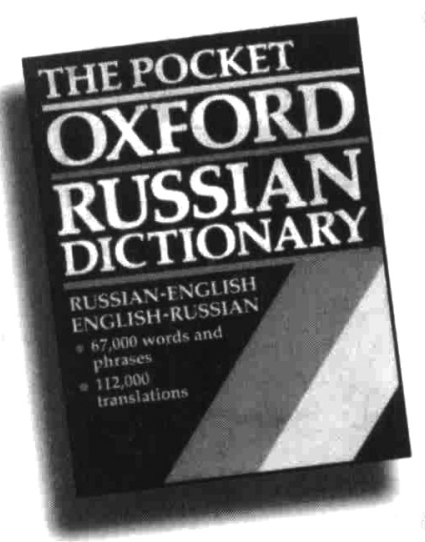

Called "the most complete and succinct" lexicon of its type by The Times Literary Supplement, this handy dictionary has long been a favorite of students, scholars, business executives, and travelers. Now in a completely revised Second Edition, it's many outstanding features include:

- More than 70,000 words and phrases

- Emphasis on modern idioms and colloquial usage

- Numerous illustrative sentences

- Guides to pronunciation, grammar, and usage

Providing the most up-to-date coverage of general vocabulary in both languages, this dictionary is an ideal companion for reading or conversation.

$\$ 19.95,640 \mathrm{pp}$.

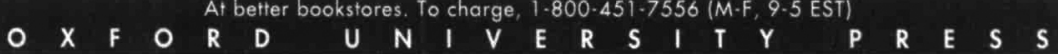


RUSSIAN-AMERICAN EDUCATIONAL. SERVICES (RAES), A DIVISION OF RUSSIAN-AMERICAN BROADCASTING COMPANY, PROVIDES A WIDE ARRAY OF PRODUCTS AND SERVICES TO ASSIST IN THE ADVANCED STUDY OF RUSSIAN LANGUAGE AND CULTURE, AS WELL AS HARD-TO-FIND AUDIO AND VIDEO MATERIALS ON VIRTUALIY ANY TOPIC CONNECTED WITH RUSSIA. OFFERINGS INCLUDE:

\section{Subscription Broadcast Services:}

-WMNB-TV, our national Russian-language TV service, broadcasts daily during prime time hours. We feature a selection of the best programs available on Russian television, direct from Moscow by satellite: WMNB-produced national and international news in Russian; the best of Russian cinematography, both classic and modern; and a variety of documentaries and special programs on Russian society and culture.

-WMNB Radio, offering sixteen hours of Russian language programming a day.

Subscribers can also access Voice-Over Interpretation Services (VoIS), an audio channel that provides simultaneous translation into Russian of selected programs on American network television. Vols is offered as a public service over RABC airwaves by the emigre non-profit group Comprehension, Inc.

Broadcast services are delivered by satellite or cable. Equipment and installation are provided by RABC.

\section{Audio/Nideo Materials:}

- A large and constantly growing selection of Russian motion pictures, either with subtitles (English or Russian) or dubbed into English.

- Film dramatizations of masterpieces of Russian literature; works by the foremost film directors of the Soviet and post-Soviet period; Stalin-era films; and the best selection of Russian cartoons and animated features available in America.

- Video documentaries and audio cassette series on Russian history and politics, on contemporary Russia, and on its literature, theater, music, art and religion.

For all who are interested in things Russian - the university professor; the high school, college or graduate student; the businessman on a crash language course or the individual studying independently - RAES offers a unique and indispensable package of learning tools.

\section{One Bridge Plaza, Suite 145, Fort Lee, New Jersey 07024 \\ For more information, call us at 1-800-722-2080 (ext. 169) or 201-461-6667 (ext. 169) Fax: 201-461-6227 Aftn: RAES}




\section{Baltic Sea Region Environmental Protection \\ "Eastern" Perspectives and International Cooperation edited by Mikael Sandberg Paper: SEK 190,00 ISBN 91-22-01517-8}

What are the prospects for Baltic Sea region environmental protection in view of the transformation of the USSR and Eastern Europe? Ten prominent social scientists from Poland, the former German Democratic Republic, Czechoslovakia, Lithuania, Latvia and Estonia present their view on the state of past, present and future environmental protection in their home countries. Economic, political, legal, technological, and historical circumstances are analyzed to make clear--given existing natural resources--what causes environmental devastation and which remedies need to be applied in the future.

\section{Almqvist \& Wiksell International \\ Alsnögatan 7, Box 4627 \\ S-11691 Stockholm, Sweden \\ Phone: $+468-6408800$ \\ Fax: $+468-6411180$}

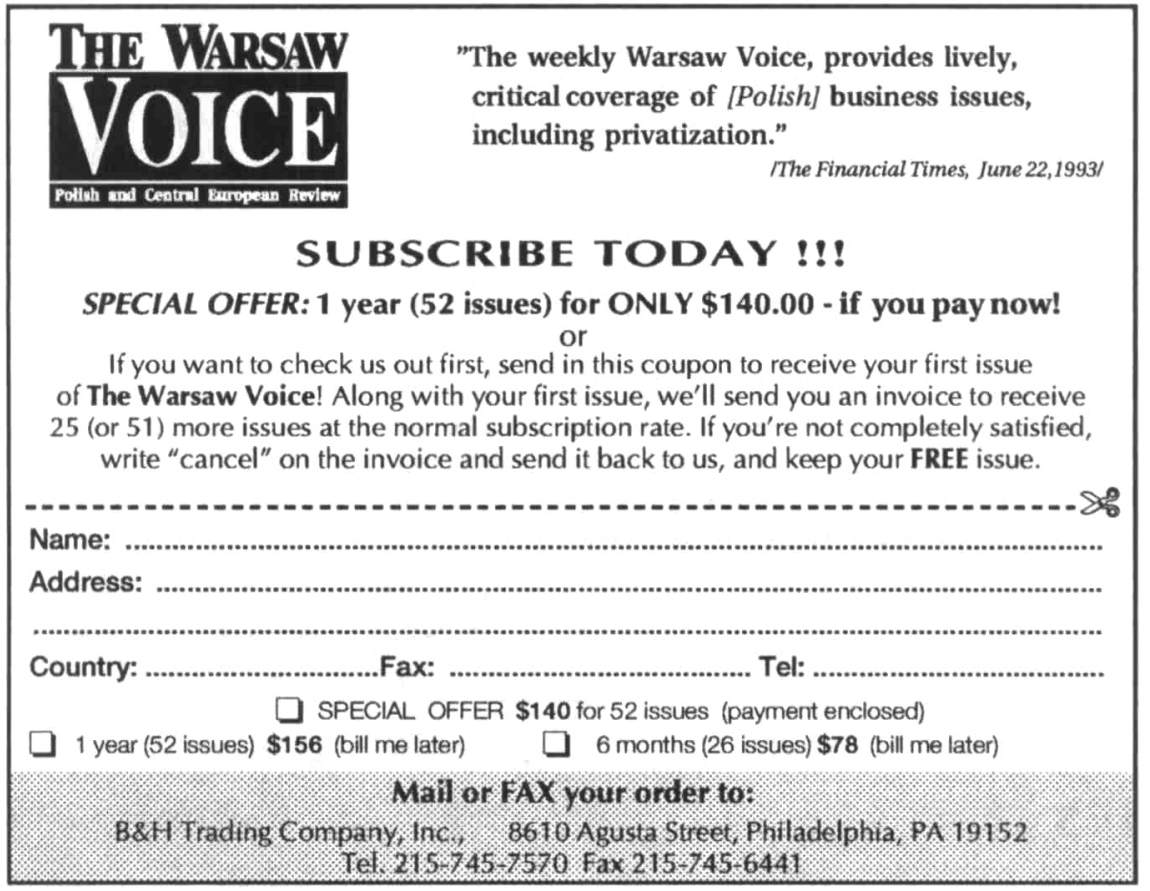




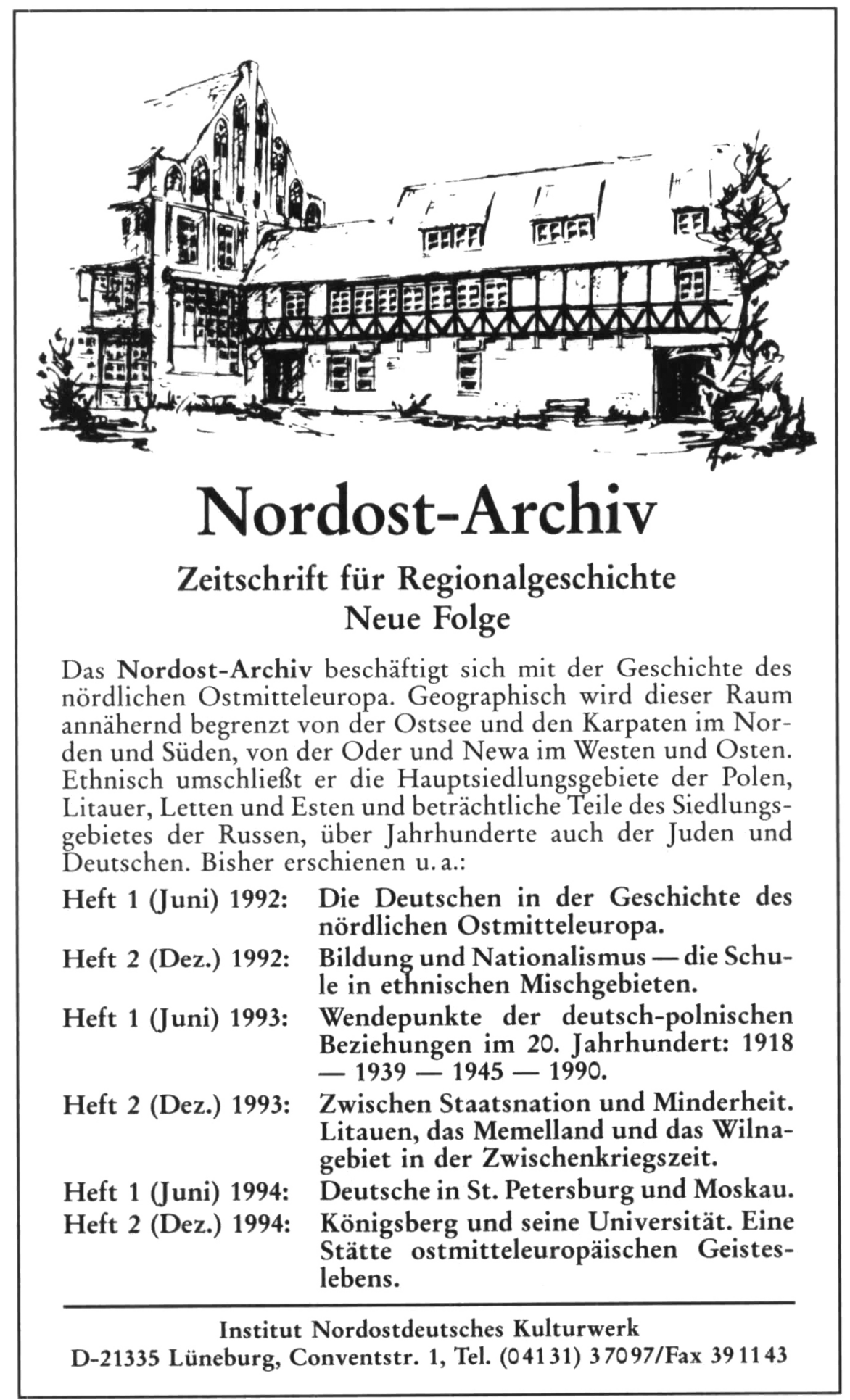




\section{MCGILL-QUEEN'S}

\section{THE YUGOSLAV DRAMA MIHAILO CRNOBRNJA}

"The Yugoslav Drama is a first-class examination of the tragedy that has overtaken that benighted country. Hopefully it will help us all learn from this disaster how to prevent similar occurrences in the future." Lawrence S. Eagleburger, former US Secretary of State.
Cloth
0-7735-1203-9
$\$ 42.95$
Paper
$0-7735-1213-6$
$\$ 15.95$

North American rights only

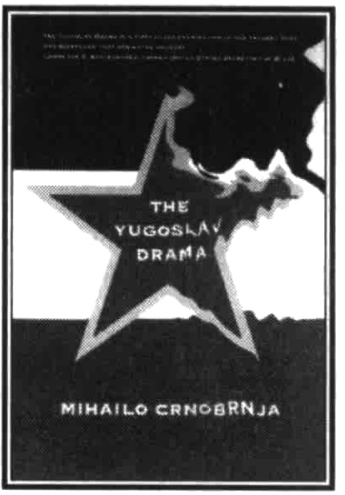

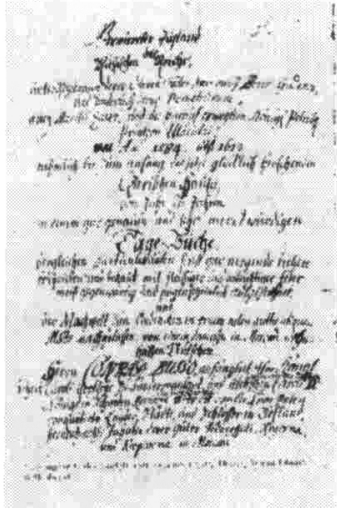

\section{PIERROT IN PETROGRAD}

Commedia dell'Arte/Balagan in Twentieth-Century Russian Theatre and Drama

\section{J. DOUGLAS CLAYTON}

An examination of the tradition of commedia dell'arte as the Russian modernists inherited it, from its origins in Italian street theatre through its various transformations.

Cloth $\quad 0-7735-1136-9 \quad \$ 49.95$

\section{THE DISTURBED STATE} OF THE RUSSIAN REALM CONRAD BUSSOW

Translated and edited by G. EDWARD ORCHARD

"Orchard provides an excellent, evenhanded, lucid coverage of political, social, and economic events at this 'absolute crossroads' in Russian history ... Bussow's memoirs are of great importance to Russian cultural history, and a wonderful book has been produced out of them." Caryl Emerson, Department of Slavic Languages and Literatures, Princeton University.

Cloth $\quad 0-7735-1165-2 \quad \$ 44.95$

\section{MCGILL-QUEEN'S UNIVERSITY PRESS} To order phone: (416) 667-779I - Or in Canada: I-800-565-9523 VISA/MasterCard accepted 


\section{NEW FROM CAMBRIDGE}

\section{Russia and the New States of Eurasia}

The Politics of Upheaval

Karen Dawisha and

\section{Bruce Parrott}

"... no mere recounting of bow the USSR broke apart but a tboughtful, carefully researcbed discussion of what arrangements might arise from the present transition pbase. Speculation is restrained and moderate, with emphasis on causes rather than results." -Library Journal 45895-1 Paperback $\$ 19.95$

\section{Between the Fields and the City}

Women, Work, and Family in Russia, 1861-1914

\section{Barbara Alpern Engel}

By examining the significance and consequences of Russian peasant women's migration from the village to the factory and city from 1861 to 1914 , this book charts the personal dimensions of economic and social change. 44236-2 Hardback $\$ 59.95$

\section{Government, Industry and Rearmament in Russia, 1900-1914}

The Last Argument of Tsarism Peter Gatrell

Using Russian archive materials, this study examines the ability of the tsarist government and Russian industrialists to respond to the multiple challenges of war, revolution, political reform, international diplomacy and rearmament in the early 20 th century.

45263-5 Hardback $\$ 74.95$

46619-9 Paperback $\$ 27.95$

\section{Modest Musorgsky and Boris Godunov}

Myths, Realities, Reconsiderations

Caryl Emerson and

Robert William Oldani

Caryl Emerson, a literary specialist, and Robert William Oldani, a music historian, take a new and comprehensive look at the most famous Russian opera, Musorgsky's Boris Godunov. The result is both a historical study of a famous work and an interpretative piece of scholarship. 36193-1 Hardback \$59.95

\section{The Social Legacy of Communism James R. Millar and Sharon L. Wolchik, Editors}

Whereas current work on the transition from communism in Eastern Europe and the former Soviet Union has emphasized the "polity" and the "economy", this book considers four basic areas: ethnic issues, deviance and health, social cleavages, and labor and elitism.

Contributors: Marjorie Mandelstam Balzer, Josepb Berliner, Walter D. Connor, Ricbard Dobson, Nicholas N. Eberstadt, Mark G. Field, Peter Juviler, Gail Kligman, Jobn Kramer, Mervyn Matthews, James R. Millar, William Moskoff, David Edward Powell, Andrea Stevenson Sanjian, Louise Shelley, Maria Todorova

Woodrow Wilson Center Press Series 46182-0 Hardback $\$ 69.95$ 46748-9 Paperback $\$ 18.95$

\section{Soviet Policy Towards South Asia Since 1970 Linda Racioppi}

This book traces the evolution of Soviet thinking about South Asia and the Third World from 1970 to the present, and examines how Soviet policy objectives changed during that period.

Cambridge Russian, Soviet and Post-Soviet Studtes 91

41457-1 Hardback $\$ 59.95$

\section{Lithuania Ascending}

A Pagan Empire within East-Central

Europe, 1295-1345

\section{S. C. Rowell}

From 1250 to 1795 Lithuania covered a vast area of eastern and central Europe. Until 1387 the country was pagan. How this huge state came to expand, defend itself against western European crusaders and play a conspicuous part in European life are the main subjects of this book. 45011-X Hardback $\$ 69.95$

Available in bookstores or from

\section{CAMBRIDGE UNIVERSITY PRESS}

40 West 20th St., N.Y., NY 10011-4211

Call toll-free 800-872-7423

MasterCard/VISA accepted.

Prices subject to change. 


\section{The Statistical Handbook of Social Indicators for the Former Soviet Union}

The Statistical Handbook of Social Indicators for the Former Soviet Union contains official statistics furnished by the national statistical services of the CIS. Providing estimates and evaluations of the socioeconomic situation in the Commonwealth States in 1985 and from 1990-1992, it is an important reference work for anyone interested in statistical data from these countries.

The Handbook provides data on all major social indicators characterizing the population of the former Soviet Union. These statistics, exchanged on a regular basis within the National Statistical Services of the former USSR countries, include data concerning standard of living, social demographics, progress in the social sphere, housing, education, culture, health, environmental conditions and crime. The Handbook includes the following sections:

- General economic indicators and summaries on production •

- Population and labor resources •

- Consumer income and spending •

- Data on consumer market conditions •

- Health, maternity and children •

- Cultural establishments, the mass media and publishing •

- Criminal activity $\bullet$ Ecological conditions $\bullet$

The Statistical Handbook of Social Indicators for the Former Soviet Union was edited, translated and prepared for publication by the Center for Human Values in Moscow. It will be updated annually.

Fall 1994 $\$ 75$

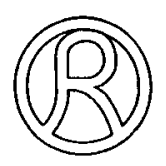

NORMAN ROSS PUBLISHING INC.

330 West 58th Street, New York, NY 10019 USA

212/765-8200 • 800/648-8850 • FAX: 212/765-2393 


\section{Northern Illinois}

\section{Russian Society and the Greek Revolution}

\section{Theophilus C. Prousis}

The Greek War of Independence captured the minds of Russians in the $1820 \mathrm{~s}$ and profoundly influenced politics, society, and the arts. Prousis explores Russian philhellenism as a force in such movements as the Decembrists' plot, the classical revival, and Romanticism.

269 pages $\$ 30.00$ cloth

\section{Coming to Terms with the Soviet Regime}

The "Changing Signposts" Movement among

Russian Émigrés in the Early 1920 s

\section{Hilde Hardeman}

As Russian émigrés faced the dilemma of accepting exile or coming to terms with the Bolsheviks, the smenovekhovstvo ("changing signposts") movement called for them to end their resistance and to rebuild Russia. Tracing the movement, Hardeman sheds new light on the interaction between the émigrés and the intellectual and political forces that dominated their homeland. 336 pages $\$ 30.00$ cloth

\section{Structures of Society}

Imperial Russia's "People of Various Ranks" Elise Kimerling Wirtschafter

Focusing on evolving definitions, Wirtschafter examines the raznochintsy - those between nobles and serfs_-as a legal, social, and cultural category. Her depiction of a porous society with shifting boundaries indicates that there was much more mobility within Imperial Russian society than historians have previously thought.

232 pages $\$ 30.00$ cloth

\section{m}

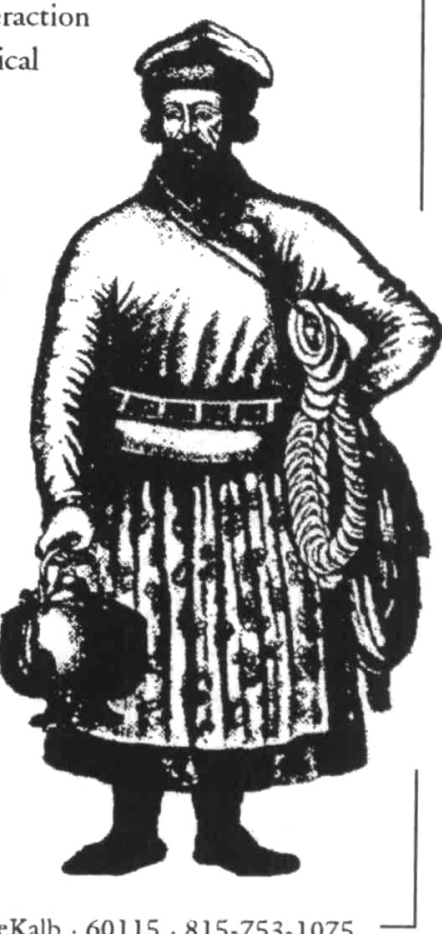

Northern Illinois University Press · DeKalb · 60115 · 815-753-1075 


\section{Statement of Ownership, \\ Circulation \\ (Required by 39 U.S.C. 3685 )}

\begin{tabular}{|c|c|c|c|c|c|}
\hline \multirow{2}{*}{$\begin{array}{l}\text { 1A. Titlo of Publication } \\
\text { Slavic Review }\end{array}$} & \multicolumn{4}{|c|}{ 18. PUBLICATION NO. } & \multirow{2}{*}{$\begin{array}{l}\text { 2. Date of Filing } \\
9 / 30 / 94\end{array}$} \\
\hline & 0 & 716 & 7 & 9 & \\
\hline $\begin{array}{l}\text { 3. Frequency of lssue } \\
\text { Quarterly }\end{array}$ & \multicolumn{3}{|c|}{$\begin{array}{l}\text { 3A. No. of lssues Published } \\
\text { Annually } \\
4\end{array}$} & \multicolumn{2}{|c|}{$\begin{array}{l}\text { 38. Annual Subscription Price } \\
\qquad 50\end{array}$} \\
\hline \multicolumn{6}{|c|}{$\begin{array}{l}\text { 4. Complete Mailing Address of Known Office of Publicetion (Street, Ciry, Counns, State and Zipt } 4 \text { Code) (Not printers) } \\
\text { American Association for the Advancement of Slavic Studies (AAASS) } \\
\text { Jordan Quad/Acacia, } 125 \text { Panama St., Stanford, CA } 94305-4130\end{array}$} \\
\hline \multicolumn{6}{|c|}{$\begin{array}{l}\text { 5. Compleze Maling Addross of the Headquarters of General Business Offices of the Publishor (Nor printer) } \\
\text { American Association for the Advancement of Slavic Studies (AAASS) } \\
\text { Jordan Quad/Acacia, } 125 \text { Panama St., Stanford, CA 94305-4130 }\end{array}$} \\
\hline \multicolumn{6}{|c|}{$\begin{array}{l}\text { 6. Full Names and Complere Mailing Address of Publisher. Editor, and Managing Editor (This Leem MUST NOT be Blank) } \\
\text { Publisher (Name and Complete Mailing Address) }\end{array}$} \\
\hline \multicolumn{6}{|c|}{$\begin{array}{l}\text { American Association for the Advancement of S7avic Studies (AAASS) } \\
\text { Jordan Quad/Acacia, } 125 \text { Panama St.. Stanford, CA 94305-4130 } \\
\text { Editor (Name and Complese Moiling dddress) }\end{array}$} \\
\hline \multicolumn{6}{|c|}{$\begin{array}{l}\text { Editor (Name and Complese Mailing Address) } \\
\text { Elliott Mossman, Slavic Review, } 636 \text { Williams Hall } \\
\text { University of Pennsylvania, Philadelphia, PA 19104-6305 }\end{array}$} \\
\hline \multicolumn{6}{|l|}{ Monsging Editor (Name and Complete Mailing Address) } \\
\hline \multicolumn{6}{|c|}{ 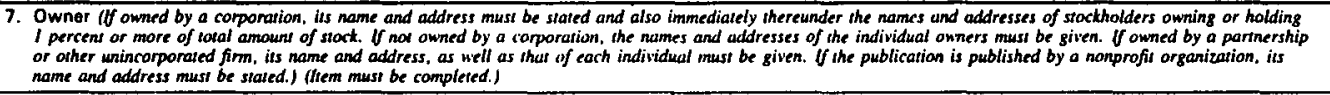 } \\
\hline Full Neme & \multicolumn{5}{|c|}{ Complote Malling Address: } \\
\hline Non-profit coproration: & \multirow{2}{*}{\multicolumn{4}{|c|}{ Jardan Quad/Acacia }} & \\
\hline American Association for the & \multirow{2}{*}{\multicolumn{5}{|c|}{ Stanford, CA $94305-4130$}} \\
\hline Advancement of slavic Studies & & & & & \\
\hline
\end{tabular}

8. Known Bondholders, Mortgagees, and Other Security Holders Owning or Holding 1 Percent of More of Totsl Amount of Bonds, Mortgages or Other Socurities (ff there are none, so state)

\begin{tabular}{|c|c|c|}
\hline Full Nams & \multicolumn{2}{|c|}{ Complate Malling Address } \\
\hline \multicolumn{3}{|l|}{ Nane. } \\
\hline \multicolumn{3}{|c|}{$\begin{array}{l}\text { 9. For Completion by Nonprofit Organizations Authorized To Mail at Special Rates (DMM Section } 124.12 \text { anly) } \\
\text { The purpose. function, and nonprofit stalus of this organization and the exempt status for Federal income tex purposes (Chect one) }\end{array}$} \\
\hline $\mathrm{XX}_{\mathrm{X}}^{(1)} \begin{array}{l}\text { Hes Not Changed During } \\
\text { Proeeding } 12 \text { Months }\end{array} \quad \square \quad \begin{array}{l}\text { (2) } \\
\text { Pros Changed During }\end{array}$ & $\begin{array}{l}\text { (If changed, pu } \\
\text { change with in }\end{array}$ & $\begin{array}{l}\text { blisher must submit eqplanation of } \\
\text { is statement.) }\end{array}$ \\
\hline $\begin{array}{l}\text { Extent and Nature of Circulation } \\
\text { (See instructions on reverse side) }\end{array}$ & $\begin{array}{l}\text { Averege No. Copies Each lssue During } \\
\text { Preceding } 12 \text { Months }\end{array}$ & $\begin{array}{l}\text { Actual No. Copies of Single lssue } \\
\text { Published Noerest to Filing Dote }\end{array}$ \\
\hline A. Total No. Copies (Net Press Run) & 4,800 & 4,800 \\
\hline $\begin{array}{l}\text { B. Paid and/or Requested Circulation } \\
\text { 1. Selos through dealore and carriers, atreet vendore and counter sales }\end{array}$ & 1,154 & 1,154 \\
\hline $\begin{array}{l}\text { 2. Moil Subacription } \\
\text { (Paid and/or requessed) }\end{array}$ & 3,399 & 3,399 \\
\hline $\begin{array}{l}\text { C. Total Paid and/or Requested Circulation } \\
\text { (Sum of } 10 B / \text { and } 10 B 2)\end{array}$ & 4,553 & 4,553 \\
\hline $\begin{array}{l}\text { D. Froo Distribution by Mall, Carribr or Other Mesns } \\
\text { Samples, Complimentary, and Other Fros Coples }\end{array}$ & 237 & 123 \\
\hline E. Total Distribution (Sum of $C$ and $D$ ) & 4,790 & 4,790 \\
\hline $\begin{array}{l}\text { F. Copios Not Distributed } \\
\text { 1. Office use, left over, unaccounted. apoiled after printing }\end{array}$ & 11 & 124 \\
\hline 2. Return from Nowa Agente & 0 & 0 \\
\hline G. TOTAL (Swm of E, FI and 2-should equal net press nun shown in A) & 4,800 & 4,800 \\
\hline $\begin{array}{l}\text { 11. I certly that the statemante made by } \\
\text { me above are correct and complete }\end{array}$ & & Ir, or Owner \\
\hline
\end{tabular}







Wil Science Press $\underset{\text { Prining Group }}{M A C K} \quad$ A Division of The Mack Printing Group

Specialists in the setting and printing of academic, technical, and medical journals

\section{Printer of Slavic Review}

Plant and Pennsylvania Sales Office 300 West Chestnut St. Ephrata, PA 17522 $717 / 738-9300$

New York Sales Office 708 Third Avenue New York, NY 10017 212/661-0786

District of Columbia Sales Office 1730 North Lynn St. Arlington, VA 22209 $703 / 528-1605$

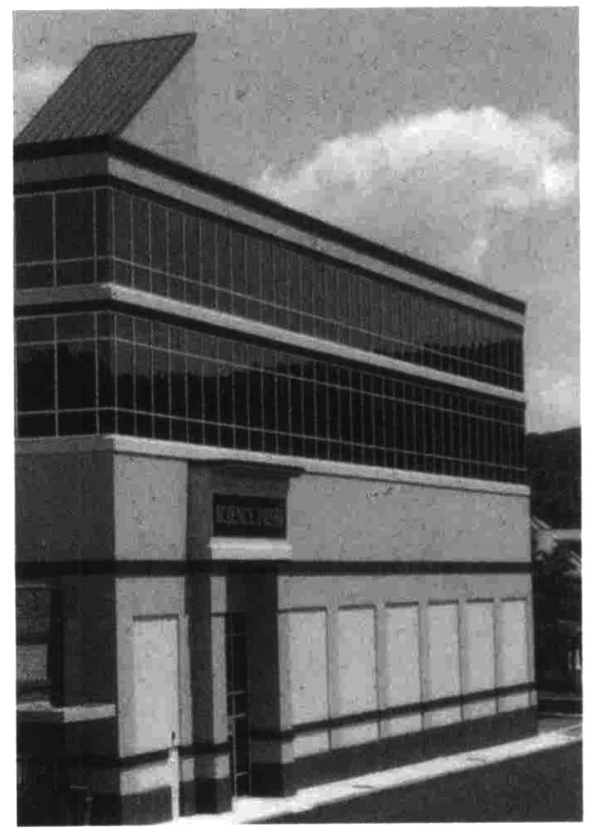

\section{Now Available!}

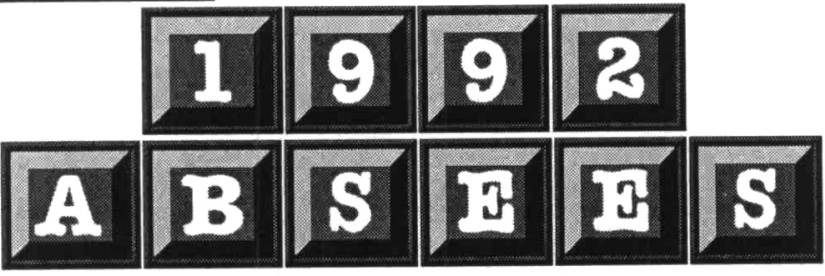

\section{American Bibliography of Slavic and East European Studies}

An invaluable bibliography of English and selected foreign-language books, journal articles, reports, dissertations and book reviews on all areas of Slavic and East European studies published in North America in 1992.

\begin{tabular}{lcc} 
& Individuals & Institutions \\
\cline { 2 - 3 } AAASS Members & $\$ 30+\mathrm{p} / \mathrm{h}^{\star}$ & $\$ 40+\mathrm{p} / \mathrm{h}^{*}$ \\
Non-members & $\$ 40+\mathrm{p} / \mathrm{h}^{\star}$ & $\$ 55+\mathrm{p} / \mathrm{h}^{*}$
\end{tabular}

*Postage \& handling: $\$ 3$ (domestic), $\$ 4$ (foreign). Add $\$ 1$ for each additional copy.

Send prepaid orders to: AAASS Jordan Quad/Acacia, 125 Panama Street, Stanford, CA 94305-4130 


\section{Automated Composition Service}

Proud supplier of quality design, composition, and page

layout services to Slavic Review as well as scholastic.

scientific, engineering, trade, mass market and

general book publishers.

Our Specialties

- complete editorial and redactory services

- foreign language composition (including non-Latin alphabets)

- mathematic and chemical composition

- SGML compatibility

- tabular composition

- disk conversions

- desktop publishing

- full art and camera services

Please contact Scott Chambers

for additional information.

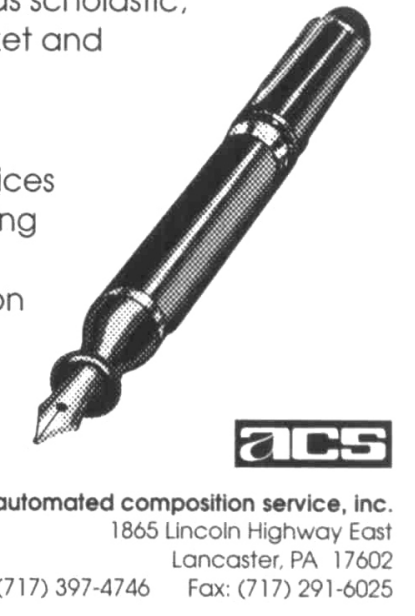

\section{TO THOSE WISHING TO SUBRAT MANUSCRIPTS}

Manuscripts for consideration should be submitted by post or courier service in four double-spaced typed copies. (If computer generated, they should be letter quality or near letter quality. Continuous form sheets must be separated.) Notes and block quotations should be dou. ble-spaced; notes should be placed at the end of the manuscript and not at the bottoms of pages. Library of Congress transliteration for quotations for fewer than 50 words and the Chicago Manual of Style are to be followed. In general, articles should not exceed 30 typed pages $8^{1 / 2^{\prime \prime}}$ by $11^{\prime \prime}$ in dimension-including endnotes.

Manuscripts are sent to outside readers in anonymous form and should be prepared accordingly.

The policy of Slavic Review is not to consider materials that have been published or that are being considered for publication elsewhere.

Publication of articles in Slavic Review is ordinarily limited to those submitted by members of AAASS. Nonmembers wishing to submit manuscripts will be sent a membership application; please see the inside front cover for information on membership. 


\section{PRIA \\ "PROMOTING RUSSIAN IN AMERICA"}

A NON PROFIT JOINT PROJECT OF THE RUSSIAN STATE COMMITTEE FOR HIGHER EDUCATION AND GRANTS RUSSIAN EXPERIENCE INC.

THE GOAL: INCREASING THE NUMBER OF STUDENTS STUDYING RUSSIAN IN AMERICA.

7330 Westmoreland Drive, Sarasota, Florida 34243

Tel.: 1-800-PYCCKOE; 813-351-1596 FAX: 813-351-8440 Moscow: 01170955921227

There has been a fall off in some areas in the number of American students studying Russian at the high school level. Dr. Henry Urbanski, the Director of the Language Immersion Institute at SUNY New Paltz and former chair of its foreign language department, advises that at a recent gathering attended by a numbel of high school teachers of Russian, fear was expressed for their jobs and a number advised that they were studying other languages to assure being retained as foreign language teachers. The annual statistics gathered by the Russian Studies Center support this concern. They show a fall off from 17,856 students studying Russian at the high school level in the 1989/1990 school year to 11,692 studying Russian at that level in the 1993/1994 school year, a $36.9 \%$ decrease. The effect of this fall off at the high school level will be increasingly felt at the college level.

The Russian Federation State Committee for Higher Education has asked Grant's Russian Experience Inc. to commence a pilot project designed to reverse this trend. The essence of the plan is to bring ovel talented young Russian college students and send them to schools offering Russian. They would hopefully be hosted by the teachers of Russian or by students at the schools now studying Russian who would be arranging for them to address their school body. In each area, we would like to team up a Russian univer. sity student with an American student studying Russian at a school relatively close to the schools to be visited.

These young Russians would be talking about economic opportunities for Americans in Russia, cultural opportunities, the excitement of being part of something akin to what happened politically in America 200 years ago, the contribution through encouragement that American students could potentially make in this area and the need to avoid a return to the adversarial relationship between our two countries which was so counter productive for the whole world. They will introduce them to Russian literature, introduce them to the Russian soul, etc. Hopefully, they will be able to reinforce all these messages with an inspirational minl music program.

Please send us the below coupon if you would like one of these young Russian college students to come to your school to attempt to help you increase the number of students studying the Russian language. Initially, we would like roughly a half the visits to be to high schools, a quarter to junior high schools feeding high schools that offer Russian and the rest to colleges.

Return to PRIA, c/o Grant's Russian Experience Inc., 7330 Westmoreland Dr., Sarasota, FL 34243

: Name

School

Address

Phone (Bus)

(Res)

FAX

I would like a young Russian college student to come to ( ) my college ( ) to my high school and/or the junior high schools feeding my high school. I would prefer the student to come

$$
\text { ( ) Fall ( ) Winter ( ) Spring '95. }
$$

( ) I would be in a position to help to recruit an American student studying the Russian language to help the Russian college student when the latter comes to schools in our area.

( ) At our school, we have some programs which have helped our Russian language enrollment which we would be willing to share with other teachers of Russian. 